\title{
Transport of dissolved trace elements in surface runoff and leachate from a Coastal Plain soil after poultry litter application
}

\author{
L.C. Kibet, A.L. Allen, C. Church, P.J.A. Kleinman, G.W. Feyereisen, L.S. Saporito, F. Hashem, E.B. \\ May, and T.R. Way
}

\begin{abstract}
The application of poultry (Gallus gallus domesticus) litter to agricultural soils may exacerbate losses of trace elements in runoff water, an emerging concern to water quality. We evaluated trace elements (arsenic [As], mercury [Hg], selenium [Se], and zinc [Zn]) in surface runoff and leachate from an agricultural soil with and without poultry litter application. Litter from a commercial operation was applied by three methods-broadcast application, subsurface placement, and broadcast application followed by disking - to no-till soils with a history of receiving litter. Soil monolith lysimeters ( 61 by 61 by $61 \mathrm{~cm})(24$ by 24 by 24 in) were extracted from each of the treatments and subjected to rainfall simulation (1 hour, 61 $\mathrm{mm} \mathrm{h}^{-1}$ [2.4 in $\left.\left.\mathrm{hr}^{-1}\right]\right) 15$ and 42 days after litter application. Broadcasting poultry litter significantly increased concentrations $\left(\mathrm{mg} \mathrm{L}^{-1}\right)$ and loads $\left(\mathrm{g} \mathrm{ha}^{-1}\right)$ of As and $\mathrm{Zn}$ in runoff during the first event relative to other application methods. Notably, incorporating litter, either by disking after broadcasting or by subsurface placement, lowered As and $\mathrm{Zn}$ in runoff to near background levels by the second event, and there were no significant differences in As and $\mathrm{Zn}$ between any of the treatments. While $\mathrm{Hg}$ and Se were detected in runoff, they likely derived from edaphic sources as they were not detected in the litter nor did they differ significantly between treatments. Results point to poultry litter as a temporary source of some trace elements to runoff. This source can be readily controlled by adjusting application method.
\end{abstract}

Key words: leachate-lysimeters—no-till—poultry litter-runoff-trace elements

The Delmarva Peninsula of the mid-Atlantic United States comprises $14,126 \mathrm{~km}^{2}$ $\left(5,454 \mathrm{mi}^{2}\right)$, is home to a poultry (Gallus gallus domesticus) industry that produces approximately 600 million birds annually (Delmarva Poultry Inc. 2009), and is estimated to generate more than $700,000 \mathrm{Mg}$ $\mathrm{y}^{-1}\left(7 \mathrm{fth}^{\mathrm{tn}} \mathrm{yr}^{-1}\right)$ of manure in the form of litter (Feyereisen et al. 2010). Most poultry litter produced on the Delmarva Peninsula is applied as an amendment to agricultural soils. In recent years, there has been heightened concern over the water quality effects of land-applied litter given the proximity of the Delmarva Peninsula to the Chesapeake Bay. Much of this concern centers on litter's contribution of nutrients to runoff. However, there is growing concern over the potential for land-applied litter to contribute other contaminants to runoff water (Kingery et al. 1994; Moore 1998; Gupta and Charles 1999; Church et al. 2010).

Poultry litter contains certain trace elements, including arsenic (As), cadmium (Cd), copper $(\mathrm{Cu})$, manganese $(\mathrm{Mn})$, lead $(\mathrm{Pb})$ and zinc (Zn). Gupta and Charles (1999) examined litter from research and commercial houses and reported significant variability in trace element content in association with differences in management practices. On average, litter tested in that study contained $37 \mathrm{mg} \mathrm{As} \mathrm{kg}{ }^{-1}, 20 \mathrm{mg} \mathrm{Cd} \mathrm{kg}{ }^{-1}, 390 \mathrm{mg} \mathrm{Cu}$ $\mathrm{kg}^{-1}, 655 \mathrm{mg} \mathrm{Mn} \mathrm{kg}^{-1}, 35 \mathrm{mg} \mathrm{Pb} \mathrm{kg}{ }^{-1}$, and $377 \mathrm{mg} \mathrm{Zn} \mathrm{kg}{ }^{-1}\left(5.89 \times 10^{-4} \mathrm{oz} \mathrm{As}^{-1} \mathrm{~b}^{-1}, 3.18\right.$ $\times 10^{-4} \mathrm{oz} \mathrm{Cd} \mathrm{lb}^{-1}, 6.2 \times 10^{-3} \mathrm{oz} \mathrm{Cu} \mathrm{lb}^{-1}, 1 \times$ $10^{-2} \mathrm{oz} \mathrm{Mn} \mathrm{lb}^{-1}, 5.56 \times 10^{-4} \mathrm{oz} \mathrm{Pb} \mathrm{lb}^{-1}, 5.99$ $\left.\times 10^{-3} \mathrm{oz} \mathrm{Zn} \mathrm{lb}{ }^{-1}\right)$. Most of these elements are added as trace element salts to increase feed efficiency as well as egg production, prevent diseases, and act as growth promoters or biocides in poultry feed (Jackson et al.
2003; Sims 1995). Arsenic is fed to chickens in the organic form of roxarsone to prevent coccidiosis, increase weight gain, and to improve feed efficiency (US Code of Federal Regulations; Garbarino et al. 2003).

Limited information exists on the fate of trace elements derived from land application of manures. Several studies have reported significant concentrations of As in soils and drainage waters of poultry operations (Moore 1998). Church et al. (2010) found that the greatest As concentrations in drainage ditch effluent were associated with point sources on a poultry farm, but also found concentrations of As to be as high as $0.026 \mathrm{mg} \mathrm{L}^{-1}(0.026 \mathrm{ppm})$ in fields draining nonpoint sources (fields that had received poultry litter as a amendment). Elsewhere, Kingery et al. (1994) observed vertical stratification of As in surface soils (Ap horizons) receiving poultry litter, with concentrations declining with depth.

There is also evidence that other trace elements, particularly $\mathrm{Zn}$ and $\mathrm{Cu}$, may either accumulate in soils amended with poultry litter or be transferred to runoff water (both surface and subsurface flow). Nicholson et al. (1999) reported that at an application level supplying $250 \mathrm{~kg}$ of $\mathrm{N} \mathrm{ha}^{-1}(280 \mathrm{lb} \mathrm{N}$ $\mathrm{ac}^{-1}$ ) of poultry manure would add 1.1 and $0.5 \mathrm{~kg} \mathrm{ha}^{-1}$ (1.2 and $0.56 \mathrm{lb} \mathrm{ac}^{-1}$ ) of $\mathrm{Cu}$ and $\mathrm{Zn}$, respectively. Elsewhere, Kingery et al. (1994) found that $\mathrm{Zn}$ accumulated in soils amended with manure up to a depth of 45 cm (18 in). Moore et al. (1998) found $\mathrm{Cu}$ and $\mathrm{Zn}$ levels in runoff as high as 0.93 and

Leonard C. Kibet is a research graduate student, Arthur L. Allen is a professor and associate research director, and Fawzy Hashem is an associate professor in the Department of Agriculture, Food and Resource Sciences, University of Maryland Eastern Shore, Princess Anne, Maryland. Clinton Church is a research chemist, Peter J.A. Kleinman is a research soil scientist, and Lou S. Saporito is a support scientist at the USDA Agricultural Research Service Pasture Systems and Watershed Management Research Unit, University Park, Pennsylvania. Gary W. Feyereisen is a research soil scientist at the USDA Agricultural Research Service Soil and Water Management Research Unit, St. Paul, Minnesota. Eric B. May is an associate professor in the Department of Natural Sciences, University of Maryland Eastern Shore, Princess Anne, Maryland. Thomas R. Way is an agricultural engineer at the USDA Agricultural Research Service National Soil Dynamics Laboratory, Auburn, Alabama. 
$0.44 \mathrm{mg} \mathrm{L}^{-1}$ (0.93 and $\left.0.44 \mathrm{ppm}\right)$ respectively, at the highest litter application rates tested $\left(8.98 \mathrm{Mg} \mathrm{ha}^{-1}\left[4 \mathrm{tn} \mathrm{ac}^{-1}\right]\right)$, indicating a potential problem to aquatic life in the case of $\mathrm{Cu}$, as it is extremely toxic to algae.

A paucity of research exists on the effects of alternative manure management methods on trace elements. Literature on managing nutrients in manures highlights application method, rate of application, and timing of application as key determinants of nutrient contamination of surface and ground waters (Sharpley et al. 2002; Gupta and Charles 1999). Significant advances have been made in the arena of land application methods for poultry litter, including the development of subsurface placement technologies formerly available only for liquid manures. These technologies have been shown to significantly reduce nutrient runoff from litter-amended soils and even increase crop yields (Pote et al. 2011). Their benefit is derived from the removal of litter from the soil surface where it serves as a concentrated source of contaminants, placing the litter near the roots of plants where litter-derived nutrients can be beneficially used. The question arises: can manure application methods that are effective in curbing runoff losses of litter-derived nutrients also affect the fate of trace elements in land applied litter?

This project evaluates the effect of conventional and novel poultry litter application methods on trace element loss in runoff and leachate from a no-till soil. Three methods of litter application-broadcasting with and without incorporation by disk tillage and subsurface application-are compared with an unamended control. Soil monolith lysimeters, collected immediately following litter application, and rainfall simulations were used to assess differences in runoff properties over time.

\section{Figure 1}

Location of University of Maryland Eastern Shore Research and Teaching Farm on the Delmarva Peninsula within the northeastern United States.

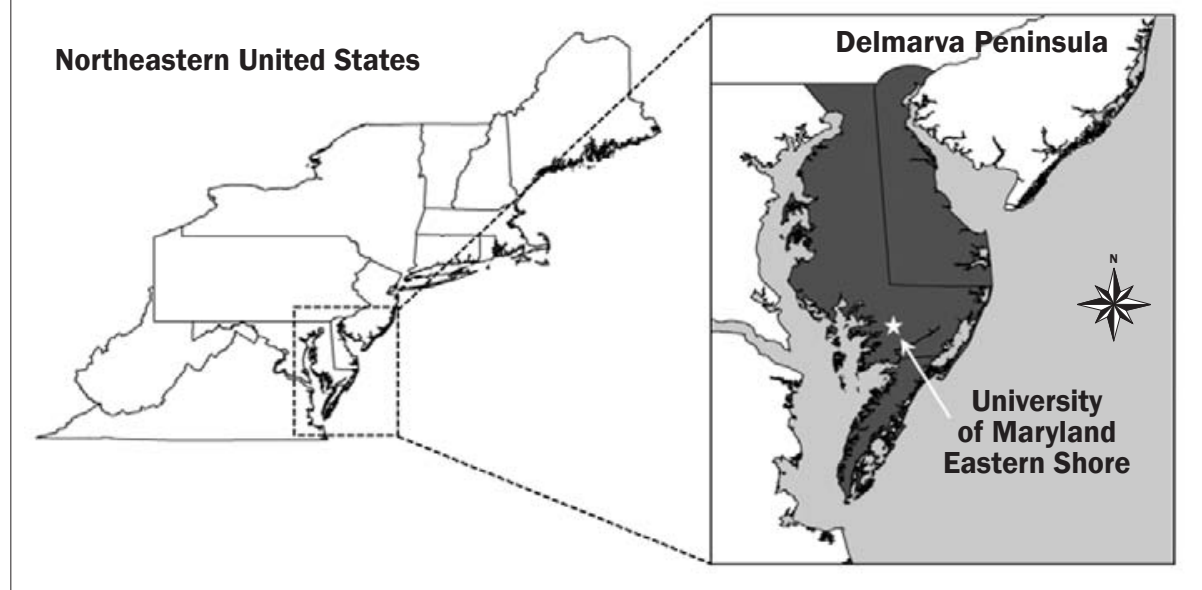

\section{Materials and Methods}

Field Site. The study was initiated at the University of Maryland Eastern Shore (UMES) Research and Teaching Farm in Princess Anne, Maryland (38 $12^{\prime} 22^{\prime \prime} \mathrm{N}$ and $\left.75^{\circ} 40^{\prime} 35^{\prime \prime} \mathrm{W}\right)$, located within the Manokin River Watershed approximately 10 km (6.2 mi) from the Chesapeake Bay (figure 1). Prior to its purchase in 1997, the farm was a commercial broiler operation with roughly 30 years of intensive litter application. Prior to that, the farm had been used for vegetable crop production, including tomato production. Fields on the Research Farm are maintained in a corn (Zea mays L.)-wheat (Triticum aestivum L.)-soybean (Glycine max L. Merr) crop rotation. The particular field used in the study had been in no-till soybean and corn production for three years, with corn planted the previous year (2007). Annual rainfall at the site averages $1,110 \mathrm{~mm}(44$ in), while annual temperature averages $13^{\circ} \mathrm{C}$ $\left(55^{\circ} \mathrm{F}\right)$ with a $25^{\circ} \mathrm{C}\left(77^{\circ} \mathrm{F}\right)$ average in July and $3^{\circ} \mathrm{C}\left(37^{\circ} \mathrm{F}\right)$ average in January.

Research was conducted on a field dominated by well-drained Matapeake soils (fine-silty, mixed, semiactive, mesic Typic Hapludults). These soils are comprised of eolian materials underlain by sandy marine sediments (Matthews and Hall 1966), resulting in a silt-loam epipedon ( $20 \%$ clay from 0 to $20 \mathrm{~cm}$ [0 to $7.9 \mathrm{in}]$ ), a silty clay loam argillic horizon $(\sim 35 \%$ clay from 35 to 45 $\mathrm{cm}$ [13.8 to $17.7 \mathrm{in}])$, and a sandy $\mathrm{C}$ horizon $(<10 \%$ clay at depths greater than 50 $\mathrm{cm}$ [19.7 in]). Surface soils possess high concentrations of phosphorus (P; Mehlich-3 P averages roughly $400 \mathrm{mg} \mathrm{kg}^{-1}\left[6.36 \times 10^{-3}\right.$ $\left.\mathrm{oz} \mathrm{lb}^{-1}\right]$ ) due to their past history of receiving poultry litter at rates often exceeding annual crop removal (Kleinman et al. 2007a). Surface soils also contain elevated concentrations of trace elements when compared with local forest soils, presumably due to long-term poultry litter application (table 1).

Litter Application Trial, Lysimeter Collection, and Soil Sampling. A trial was established in 2008 to compare three different methods of manure applicationconventional broadcast application with and without incorporation by disk tillage and subsurface application - with an unamended

\section{Table 1}

Antecedent soil trace elements (o to $5 \mathrm{~cm}$ depth) as influenced by historical manure application and University of Maryland Eastern Shore forest soils.

\begin{tabular}{lcllll}
\hline Treatments & $\mathbf{N}$ & Arsenic $\left(\mathbf{m g ~ k g}^{-\mathbf{1}}\right)$ & Mercury $\left(\mathbf{m g ~ k g}^{-\mathbf{1}}\right)$ & Zinc $\left(\mathbf{m g ~ k g}^{\mathbf{- 1}}\right)$ & ${\mathbf{S e l e n i u m ~}\left(\mathbf{m g ~ k g}^{-\mathbf{1}}\right)}$ \\
\hline No manure & 5 & $0.7(0.05)$ & $0.02(0.01)$ & $21.29(1.93)$ & $0.13(0.08)$ \\
Broadcast & 5 & $0.62(0.05)$ & $0.00(0.00)$ & $18.66(0.55)$ & $0.15(0.05)$ \\
Disked & 5 & $0.64(0.08)$ & $0.01(0.01)$ & $18.46(3.86)$ & $0.15(0.06)$ \\
Subsurface & 5 & $0.68(0.10)$ & $0.04(0.04)$ & $20.20(2.37)$ & $0.21(0.03)$ \\
Forest soils & 20 & $0.07(0.01)$ & BDL & $6.45(0.38)$ & $0.18(0.06)$ \\
\hline
\end{tabular}

Notes: Standard error of means are given in parentheses next to the means. $\mathrm{N}=$ number of samples. $\mathrm{BDL}=$ below detection limit. 
control. The subsurface application technology used in the trial was developed by the USDA Agricultural Research Service Soil Dynamics Laboratory (Auburn, Alabama) and is described in detail by Pote et al. (2011). The subsurface application unit was configured to place litter in an $8 \mathrm{~cm}$ (3.1 in) deep furrow at $76 \mathrm{~cm}$ (29.9 in) intervals, with a press wheel closing the furrow so that litter was not exposed to the surface.

Experimental plots ( 6 by $3 \mathrm{~m}$ ) (19.7 by 9.8 $\mathrm{ft}$ ) were established on the research field, and litter from the Research Farm was applied to all plots except the control on April 16, 2008, at a rate of $6.7 \mathrm{Mg} \mathrm{ha}^{-1}\left(2.24 \mathrm{tn} \mathrm{ac}^{-1}\right)$. Disking of litter was conducted within one hour of broadcast application. The UMES Research Farm maintains three commercial poultry houses rearing 90,000 broilers per house annually. Litter from the houses is stored in an open sided shed for approximately 10 months prior to land application. Litter was sampled and analyzed approximately 1 month prior to its use in the field trial.

Immediately following poultry litter applications, five monolith lysimeters (61 by 61 by $61 \mathrm{~cm}$ ) (24 by 24 by 24 in) were extracted from each plot, totaling five lysimeters per treatment. For the subsurface application treatment, the litter band was centered in the lysimeter, perpendicular to the anticipated flow of runoff water during the subsequent rainfall simulation experiments. The lysimeters, which are specifically constructed to allow the simultaneous collection of runoff and leachate, were described in detail by Feyereisen and Folmar (2009) and are depicted in figure 2. Briefly, a steel casing surrounding polyvinyl chloride (PVC) walls was driven into the ground by a $1.1 \mathrm{Mg}(1.2$ tn) drop weight, with careful attention to ensure that the weight did not contact the soil surface. The complete assembly was excavated and inverted to install the bottom plate and collection pan. Soils were then righted to normal orientation and transported to the USDA Agricultural Research Service Pasture Systems and Watershed Management Research Unit's field station in Klingerstown, Pennsylvania. At the field station, the PVC walls were removed to create a space between the steel casing and the intact soil column. Petrolatum was poured into the gap to seal the soil and prevent bypass flow.

To represent antecedent soil conditions in the lysimeters, three soil cores (0 to 15 $\mathrm{cm}$ [0 to 6 in]) were collected adjacent to each lysimeter at the time of extraction and blended to form a single composite sample. To contrast agricultural soil conditions with those found in forest soils with no litter application history, triplicate cores $(15.2 \mathrm{~cm})$ (6 in) were also collected from 20 sites in an adjacent forest and blended to form a composite sample for each forested site.

\section{Rainfall Simulation Experiment.}

Lysimeters were grouped in five blocks of four for the rainfall simulation experiments, with each block of lysimeters containing one of each treatment (figure 2). To minimize potential bias associated with rainfall distribution, the relative position of each treatment was varied across lysimeter blocks. A portable rainfall simulator equipped with a TeeJetTM 1/2 HH SS 30 WSQ nozzle (Spraying Systems Co., Wheaton, Illinois) was placed approximately $3 \mathrm{~m}(9.8 \mathrm{ft})$ above the soil surface of each block of lysimeters (figure 2) so that simulated rainfall falling at $61 \mathrm{~mm} \mathrm{~h}^{-1}\left(2.4 \mathrm{in} \mathrm{hr}^{-1}\right)$ could achieve at least $90 \%$ terminal velocity. The coefficient of uniformity for rainfall across each block of lysimeters averaged 0.85 , determined by raining on four 60 by $60 \mathrm{~cm}$ (24 by $24 \mathrm{in}$ ) containers positioned to represent the surface of each monolith lysimeter.

Lysimeters were subjected to 1-hour rainfall simulations (61 $\mathrm{mm}$ [2.4 in] precipitation) on May 1 and June 12, 2008 (15 and 42 days after litter application), using a modified version of the National Phosphorus Research Project protocol (Kleinman et al. 2004). In between simulated rainfall events, lysimeters were irrigated by hand semiweekly (11 events), with the total irrigation depth approximating the 30-year average precipitation for the research site during March and April. Immediately prior to each rainfall simulation, antecedent soil moisture within the upper $4 \mathrm{~cm}$ (1.6 in) of each lysimeter was measured by capacitance sensor (Theta Probe, Delta-T Devices Ltd., Cambridge, UK). Surface runoff was collected in plastic pails that were weighed (to determine volume) at 5-minute intervals during runoff events. Leachate draining from the lysimeters was weighed and sampled 24 hours after the event. Surface runoff and leachate samples were filtered $(0.45 \mu \mathrm{m}$ $[0.000018$ in] $)$ and stored at $4^{\circ} \mathrm{C}\left(39.4^{\circ} \mathrm{F}\right)$ prior to laboratory analysis.

Laboratory Analyses. Soil samples were air dried and sieved (2 mm [0.079 in]) prior to analysis. Total concentrations of trace elements in soil were determined by aqua regia digestion, with $1 \mathrm{~g}(0.36 \mathrm{oz})$ soil digested in $10 \mathrm{~mL}(0.34 \mathrm{oz})$ aqua-regia $(25 \% 12 \mathrm{M}$ $\left.\mathrm{HNO}_{3}+75 \% 12 \mathrm{M} \mathrm{HCl}\right)$ for two hours at $95^{\circ} \mathrm{C} \pm 5^{\circ} \mathrm{C}\left(203^{\circ} \mathrm{F} \pm 9^{\circ} \mathrm{F}\right)$. Digests were analyzed by inductively coupled plasma-optical emission spectrometry (ICP-OES) for trace element content (table 1).

Poultry litter was analyzed for trace elements, $\mathrm{pH}$, and dry matter content (table 2). Total trace element content was determined by digesting $0.5 \mathrm{~g}(0.018 \mathrm{oz})$ samples of fresh litter in $10 \mathrm{~mL}(0.34 \mathrm{oz})$ aqua-regia $(25 \% 12$ $\mathrm{M} \mathrm{HNO}_{3}+75 \% 12 \mathrm{M} \mathrm{HCl}$ ) for 2 hours at $95^{\circ} \mathrm{C} \pm 5^{\circ} \mathrm{C}\left(203^{\circ} \mathrm{F} \pm 9^{\circ} \mathrm{F}\right)$. Trace elements in water extracts and aqua-regia digests were determined by ICP-OES.

For runoff and leachate waters, filtered $(0.45 \mu \mathrm{m}$ [0.000018 in]) water samples were analyzed for P, As, Hg, Se, and Zn by ICPOES. Detection limits for the trace elements reported in this study were $0.01 \mathrm{mg} \mathrm{L^{-1 }}$ (0.01 ppm). Total solids were determined on unfiltered samples by gravimetric analysis, after evaporating $200 \mathrm{~mL}$ (6.76 oz) of runoff water at $80^{\circ} \mathrm{C}\left(176^{\circ} \mathrm{F}\right)$. Loads were calculated by multiplying concentration by runoff volume at five-minute intervals for individual lysimeters and then averaging results across the five lysimeters for that treatment.

Data were analyzed by conventional parametric statistics using SAS v.9.1 (SAS Institute 2000). Some surface runoff and leachate samples had trace element concentrations (As, $\mathrm{Hg}$, and selenium [Se]) that fell below the analytical detection limit $(0.01 \mathrm{mg}$ $\mathrm{L}^{-1}[0.01 \mathrm{ppm}]$ for As and Se and $0.005 \mathrm{mg} \mathrm{L}^{-1}$ [0.005 ppm] for $\mathrm{Hg}$ ) and were not included in statistical analyses. Differences among treatments were evaluated by general linear model, and individual treatment means were grouped by Tukey's pair-wise comparison. Statistical results were considered significant at $\alpha=0.05$. Relationships between variables were assessed by least squares regression or Pearson's correlation analysis.

\section{Results and Discussion}

Soils and Litter. Total concentrations of trace elements in poultry litter, in soils obtained from the study site on the UMES Research and Teaching Farm, and an adjacent forest provide insight into applied and edaphic sources of trace elements (tables 1 and 2). Respective concentrations of $\mathrm{As}$ and $\mathrm{Zn}$ in poultry litter were threefold and twofold 


\section{Figure 2}

Schematic of monolith lysimeters designed to allow simultaneous collection of surface runoff and leachate.

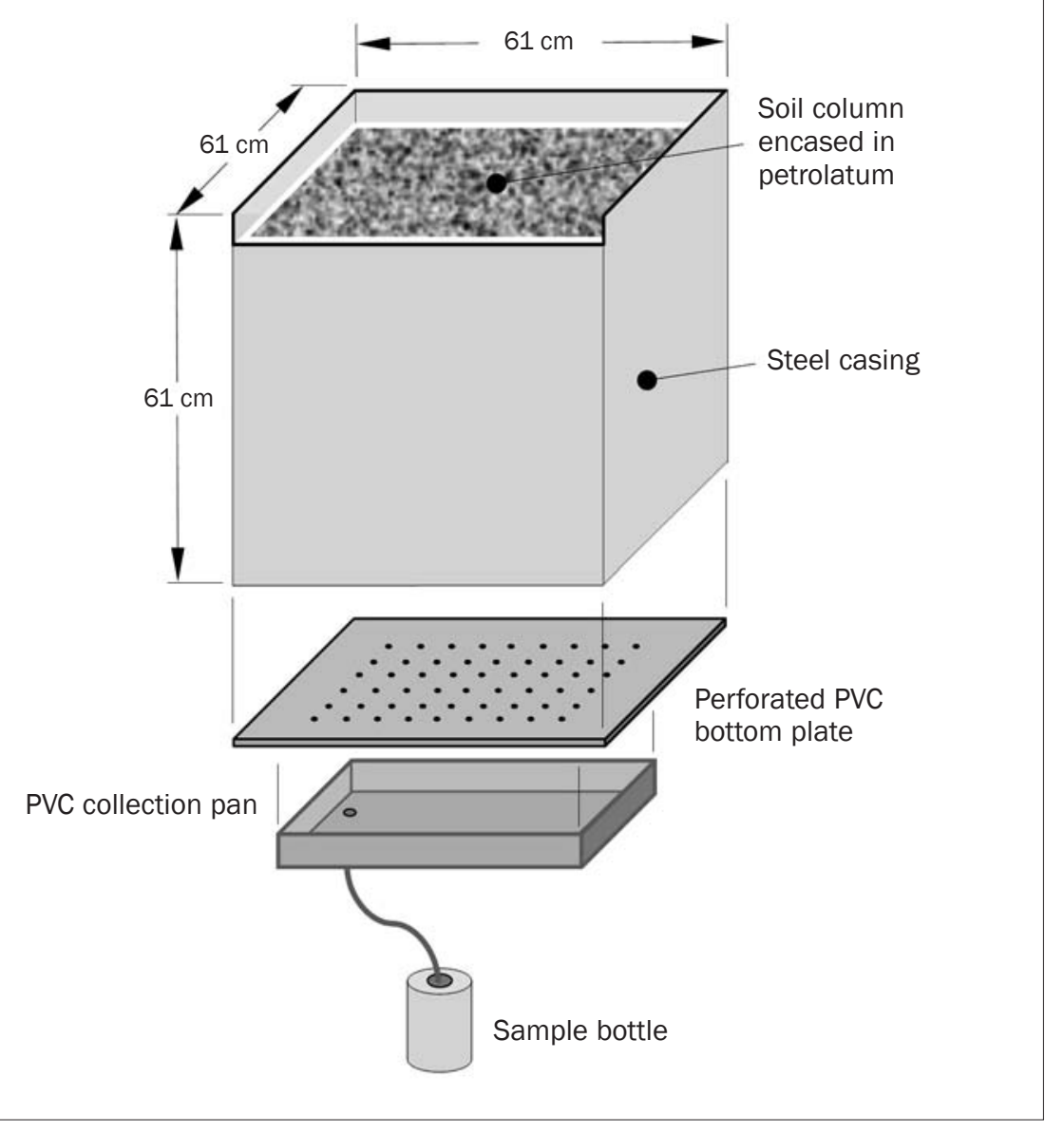

\section{Table 2}

Mean concentrations of trace elements in the poultry litter used for the study.

\begin{tabular}{lll}
\hline $\begin{array}{l}\text { Trace } \\
\text { elements }\end{array}$ & $\mathbf{N}$ & $\begin{array}{l}\text { Concentration } \\
(\mathbf{m g ~ k g - 1})\end{array}$ \\
\hline Arsenic & 10 & $2.21(0.140)$ \\
Zinc & 10 & $38.5(1.67)$ \\
Selenium & 10 & BDL \\
Mercury & 10 & BDL \\
\hline
\end{tabular}

Notes: Standard error of means are given in parentheses next to the means. $\mathrm{N}=$ number of samples. $\mathrm{BDL}=$ below detection limit.

greater than in the agricultural soils and sixfold greater than in the forest soils. Neither Se nor $\mathrm{Hg}$ was found in the poultry litter. Concentrations of Se were found in roughly equal amounts across all soils examined (agricultural and forest). Concentrations of $\mathrm{Hg}$ in the agricultural soils averaged 0.02 $\mathrm{mg} \mathrm{kg}^{-1}\left(3.18 \times 10^{-7} \mathrm{oz} \mathrm{lb}^{-1}\right)$, but fell below the detection limit in the forest soils. The elevated $\mathrm{Hg}$ concentrations in the agricultural soils may reflect historical application of fungicide to tomatoes, as tomatoes had been grown on the site from the 1950s and 1960s, during which time $\mathrm{Hg}$-containing fungicides were widely used on vegetable crops. High levels may also reflect more recent usage of $\mathrm{Hg}$-containing pesticides that were not banned until 1995 (e.g., mercurous and mercuric chloride, phenylmercury acetate, phenylmercury salicilate, and ethyl mercury phosphate) (Gilkeson 2002).

Surface Runoff. Surface runoff volumes from the lysimeters exhibited similar patterns across treatments over the two events, although differences were not statistically significant in the first event due to high variability (table 3 ). Surface runoff volumes from the disked treatment were significantly lower than from the other treatments in the second event and across the two events (total surface runoff) and were lower in the first event, albeit not statistically. As illustrated by mean hydrographs for each treatment (figure 3), flows during each event were lower for the disked treatment than for the other treatments. Surface runoff from the disked treatment began later than the other three, although it lasted slightly longer after cessation of rainfall. The lesser flows and cumulative volumes associated with disking were likely due to increased infiltration (also supported by greater, nonsignificant leachate volumes) caused by greater surface storage following tillage (Kleinman et al. 2009) and greater flow path tortuosity/surface roughness (Verbree et al. 2010).

Trace Element Concentrations in Surface Runoff. Trace element concentrations (mg $\mathrm{L}^{-1}$ ) observed in surface runoff fell into two categories of trends, depending upon their likely source: applied poultry litter (As and $\mathrm{Zn}$ ) or edaphic ( $\mathrm{Hg}$ and $\mathrm{Se}$ ). Concentrations of Se in surface runoff fell below the analytical detection limit of $0.01 \mathrm{mg} \mathrm{L}^{-1}(0.01$ ppm) (table 3).

Dissolved As and $\mathrm{Zn}$ chemographs in surface runoff during the first rainfall event were consistent with those reported elsewhere for elements derived from applied sources, reflecting depletion of the applied source by runoff water (McDowell and Sharpley 2002). Specifically, concentrations were highest at the beginning of the first event and tapered off to near background levels (represented by the control treatment) as surface runoff proceeded (figure 4). By the second event, no significant trends in trace element chemographs were detectable across all treatments. By means of comparison, $\mathrm{P}$, also applied in poultry litter, followed a trend generally similar to As and $\mathrm{Zn}$ (figure 4), although concentrations of $\mathrm{P}$ in surface runoff from the broadcast treatment remained fourfold higher than background concentrations at the end of the first event.

Across the four treatments, the highest concentrations of As and $\mathrm{Zn}$ in the first event were associated with broadcast litter application, reflecting exposure of the poultry litter to runoff waters, while the disked and subsurface treatments were not significantly different from the control (figure 4 and table 3). Our study confirms the well-established observation that incorporation of litter diminishes the incidental transfer, or wash off, of surface applied constituents (Maguire et al. 2011). During the second rainfall event, concentrations of As and $\mathrm{Zn}$ in surface runoff from the broadcast and disked treatments 
Table 3

Mean trace element concentrations in surface runoff and leachate from two rainfall simulation events.

\begin{tabular}{|c|c|c|c|c|c|c|c|c|c|c|c|}
\hline \multirow[b]{2}{*}{ Treatment } & \multirow[b]{2}{*}{$\mathbf{N}$} & \multicolumn{2}{|c|}{ Arsenic (mg L-1) } & \multicolumn{2}{|c|}{ Mercury (mg L-1) } & \multicolumn{2}{|c|}{ Selenium (mg L-1) } & \multicolumn{2}{|c|}{ Zinc $\left(\mathrm{mg} \mathrm{L}^{-1}\right)$} & \multirow[b]{2}{*}{$\begin{array}{l}\text { Runoff } \\
\text { depth (cm) }\end{array}$} & \multirow[b]{2}{*}{$\begin{array}{l}\text { Leachate } \\
\text { depth }(\mathrm{cm}\end{array}$} \\
\hline & & $\begin{array}{l}\text { Surface } \\
\text { runoff }\end{array}$ & Leachate & $\begin{array}{l}\text { Surface } \\
\text { runoff }\end{array}$ & Leachate & $\begin{array}{l}\text { Surface } \\
\text { runoff }\end{array}$ & Leachate & $\begin{array}{l}\text { Surface } \\
\text { runoff }\end{array}$ & Leachate & & \\
\hline \multicolumn{12}{|c|}{ 1st rainfall simulation (15 d after litter application) } \\
\hline Control & 5 & $0.007 \mathrm{~b}$ & $0.006 \mathrm{~b}$ & $0.010 a$ & $0.039 a$ & $<0.01$ & $0.010 a$ & $0.040 \mathrm{~b}$ & $0.052 a$ & $3.48 a$ & $0.89 a$ \\
\hline Broadcast & 5 & $0.031 a$ & $0.011 a b$ & $0.009 a$ & $0.030 a$ & $<0.01$ & $0.013 a$ & $0.202 a$ & $0.350 a$ & $3.81 a$ & $1.32 a$ \\
\hline Broadcast/disked & 5 & $0.017 a b$ & $0.007 b$ & $0.009 a$ & $0.039 a$ & $<0.01$ & $0.010 a$ & $0.149 a b$ & $0.272 a$ & $2.43 a$ & $1.66 a$ \\
\hline Subsurface & 5 & $0.021 a b$ & $0.028 a$ & $0.013 a$ & $0.046 a$ & $<0.01$ & $0.015 a$ & $0.148 a b$ & $0.354 a$ & $3.47 a$ & $0.77 a$ \\
\hline \multicolumn{12}{|c|}{ 2nd rainfall simulation (42 d after litter application) } \\
\hline Control & 5 & $0.006 b$ & $<0.01$ & $<0.01$ & $<0.01$ & $<0.01$ & $<0.01$ & $0.025 a$ & $0.025 a$ & $4.31 a$ & $1.11 \mathrm{a}$ \\
\hline Broadcast & 5 & $0.010 a b$ & $<0.01$ & $<0.01$ & $<0.01$ & $<0.01$ & $<0.01$ & $0.053 a$ & $0.035 a$ & $4.61 \mathrm{a}$ & $1.08 a$ \\
\hline Broadcast/disked & 5 & $0.011 a b$ & $<0.01$ & $<0.01$ & $<0.01$ & $<0.01$ & $<0.01$ & $0.040 a$ & $0.036 a$ & $2.70 b$ & $1.55 a$ \\
\hline Subsurface & 5 & $0.018 a$ & $<0.01$ & $<0.01$ & $<0.01$ & $<0.01$ & $<0.01$ & $0.042 a$ & $0.047 a$ & $3.75 a$ & $1.26 a$ \\
\hline \multicolumn{12}{|c|}{ Average properties across both rainfall simulation events } \\
\hline Control & 5 & $0.006 b$ & $0.006 a$ & $0.008 a$ & $0.022 a$ & $<0.01$ & $0.008 a$ & $0.033 b$ & $0.039 a$ & $7.79 a$ & $2.00 a$ \\
\hline Broadcast & 5 & $0.020 a$ & $0.008 a$ & $0.007 a$ & $0.018 a$ & $<0.01$ & $0.009 a$ & $0.127 a$ & $0.239 a$ & $8.42 a$ & $2.40 a$ \\
\hline Broadcast/disked & 5 & $0.014 a b$ & $0.006 a$ & $0.007 a$ & $0.022 a$ & $<0.01$ & $0.007 a$ & $0.095 a b$ & $0.154 a$ & $5.13 b$ & $3.21 a$ \\
\hline Subsurface & 5 & $0.019 a b$ & $0.017 a$ & $0.009 a$ & $0.025 a$ & $<0.01$ & $0.011 a$ & $0.095 a b$ & $0.201 a$ & $7.22 a$ & $2.03 a$ \\
\hline
\end{tabular}

Notes: Values followed by different letters identify groupings per Tukey's mean separation analysis. $\alpha=0.05$. $N=$ number of samples. $<0.01=$ below method detection limit.

\section{Figure 3}

Hydrographs for (a) rainfall simulation event 1 and (b) rainfall simulation event 2, showing mean overland flow for the four poultry litter application treatments.

(a)

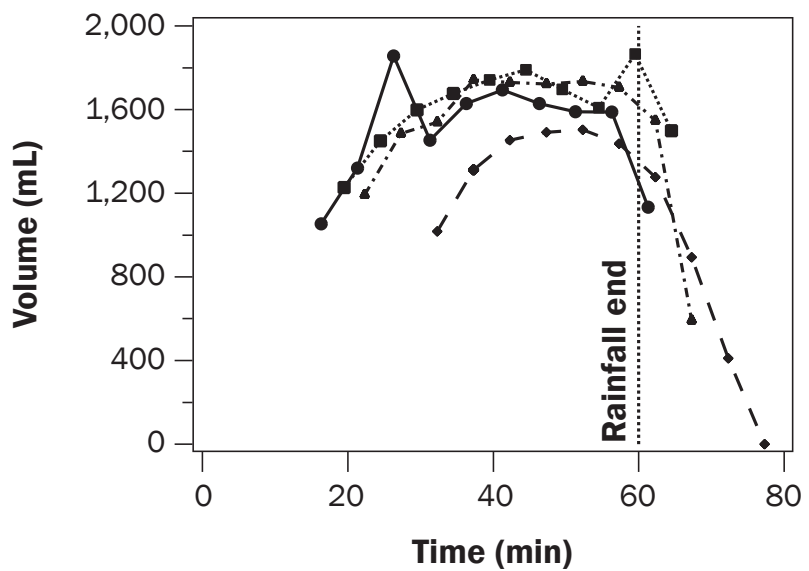

(b)

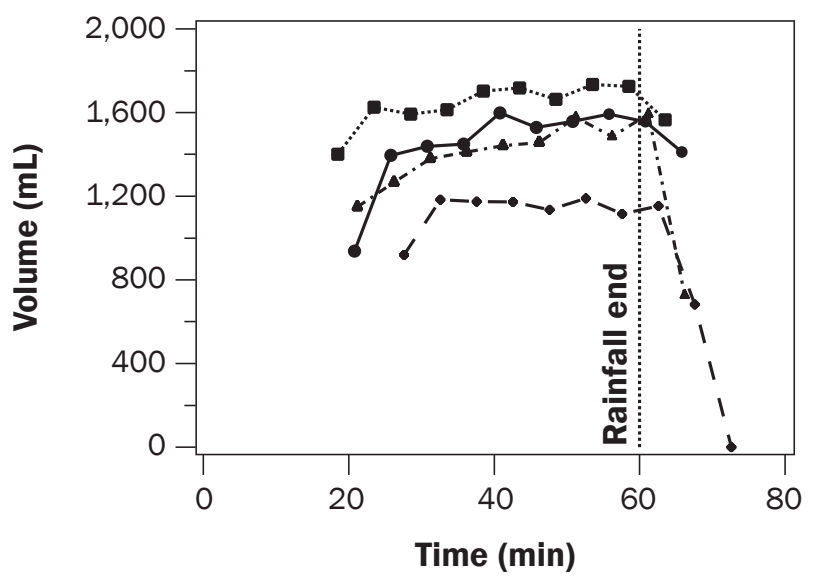

were not statistically different from the control except for As in the subsurface treatment.

Notably, most concentrations of As in surface runoff for all methods of litter application were above the EPA Standard for drinking water $\left(0.01 \mathrm{mg} \mathrm{L}{ }^{-1}[0.01 \mathrm{ppm}] \mathrm{As}\right)$ for both rainfall events (USEPA 2009), with one observed concentration for the broadcast treatment measured as seven times greater. In a previous investigation of As fate at the UMES Research and Teaching Farm (source of the soils used in this study), Church et al. (2010) found comparable concentrations in ditch runoff.

Mercury concentrations in surface runoff (figure 5) during the first event stand in contrast to those observed for As and $\mathrm{Zn}$. In general, there was no discernable pattern in concentrations, which suggests an edaphic source and is consistent with the findings of no detectable $\mathrm{Hg}$ in the poultry litter (table 2). Furthermore, no significant differences in $\mathrm{Hg}$ concentrations in surface runoff were detected between treatments, supporting the 


\section{Figure 4}

Surface runoff chemographs of trace elements ([a and b] zinc and [c and d] arsenic) and (e and f) phosphorus for the (a, c, and e) first and (b, d, and f) second rainfall simulation events. Discontinuous records indicate that some of the observations along the hydrograph were below the analytical detection limit for that element.

(a)

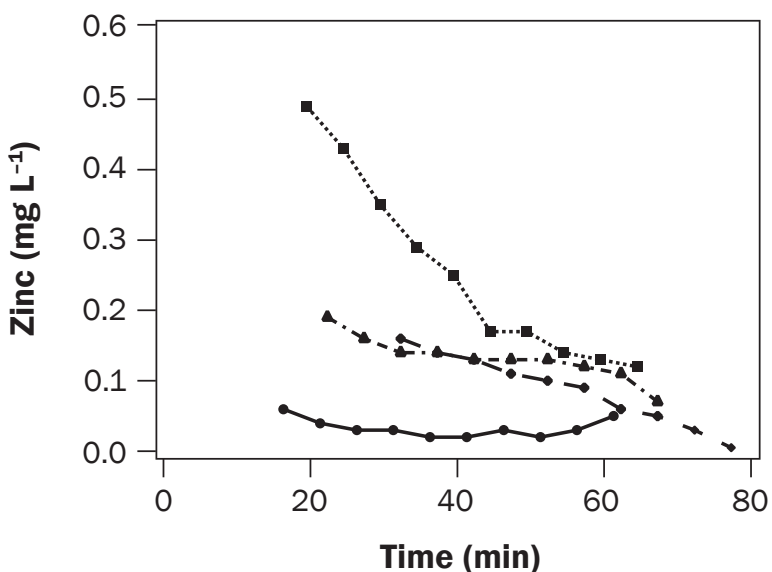

(c)

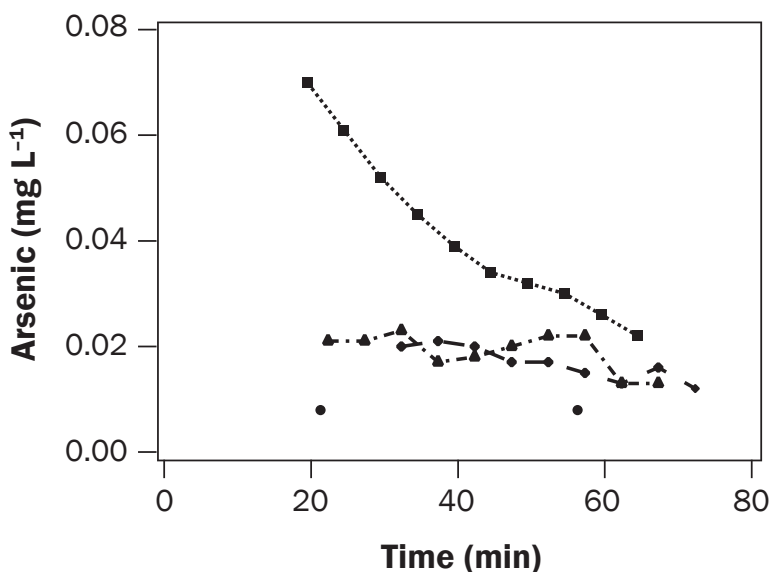

(e)

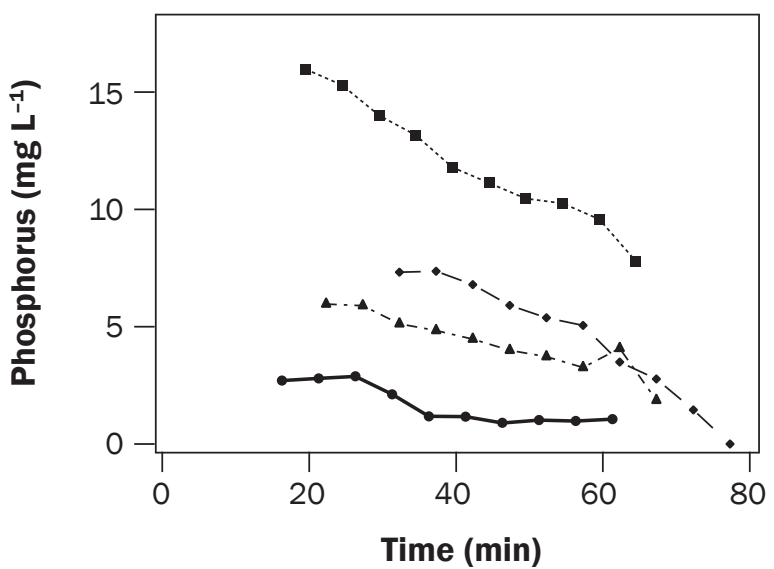

(b)

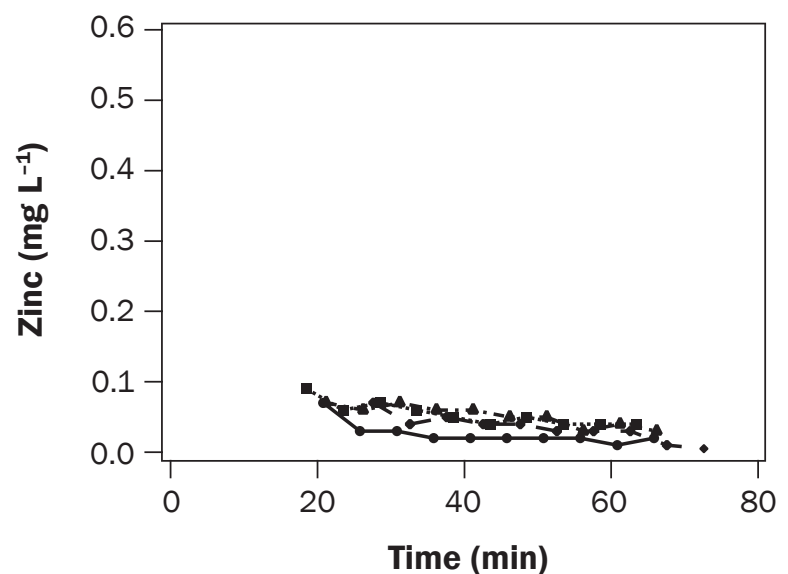

(d)

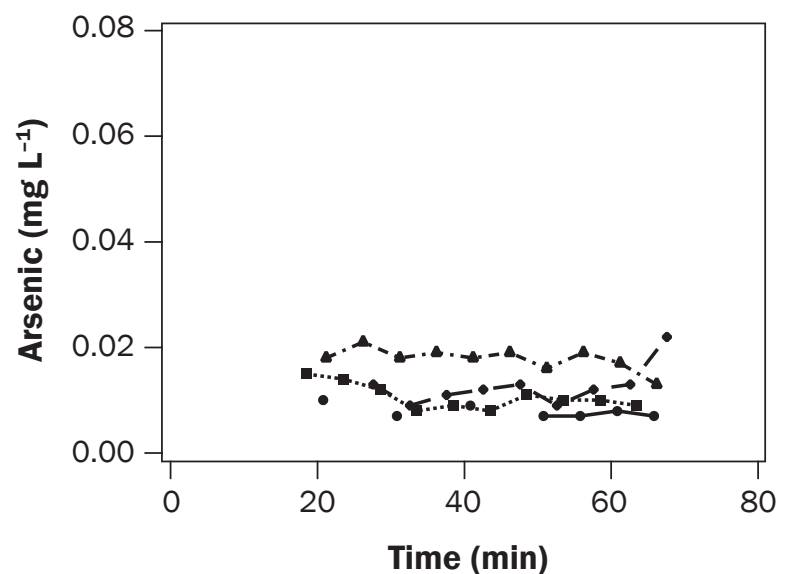

(f)

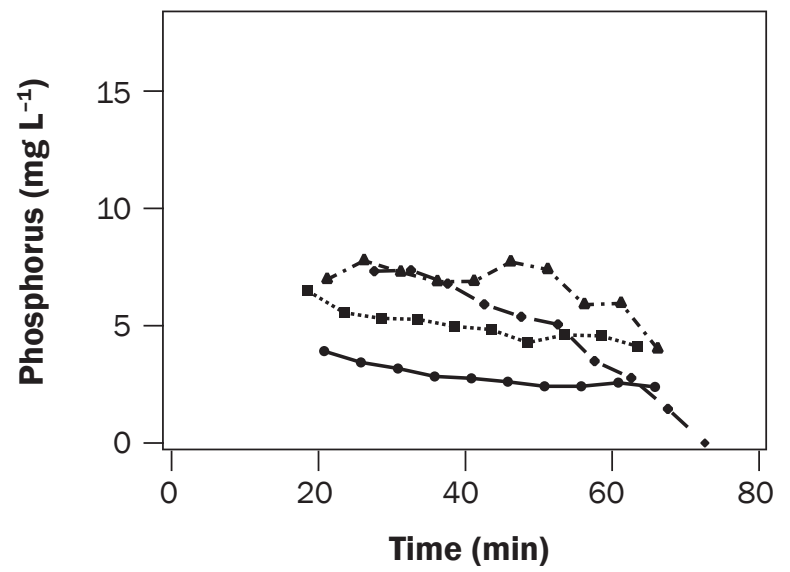

\section{Legend}

$\multimap$ Control

Broadcast

Disked

- Subsurface 
conclusion that $\mathrm{Hg}$ derived from edaphic sources (i.e., treatments involved manipulations of applied litter). Whereas almost all $\mathrm{Hg}$ concentrations in surface runoff from the first rainfall event were above the limit set by the US Environmental Protection Agency for drinking water $\left(0.002 \mathrm{mg} \mathrm{L}^{-1}[0.002\right.$ ppm]; USEPA 2009), concentrations of $\mathrm{Hg}$ in surface runoff from the second event were below the analytical detection limit of the ICP-OES (0.005 $\left.\mathrm{mg} \mathrm{L}^{-1}[0.005 \mathrm{ppm}]\right)$. Differences in $\mathrm{Hg}$ concentrations between the two events suggest that the mobile $\mathrm{Hg}$ was either removed by runoff during the first rainfall event, immobilized by biotic or abiotic processes, or volatilized (Adams et al. 2007; Porvari and Verta 1995).

Trace Element Loads in Surface Runoff. Trace element loads in runoff, expressed as a specific yield $\left(\mathrm{g} \mathrm{ha}^{-1}\right)$, were higher for As and $\mathrm{Zn}$ than for $\mathrm{Hg}$ in surface runoff. Trends in As and $\mathrm{Zn}$ loads between litter application treatments were similar to those described above for trace element concentrations in runoff and correlated well with concentrations ( $r=0.95$ for As and $r=0.96$ for $\mathrm{Zn}$ ). In contrast, As and Zn loads were poorly related to runoff depths $(r<0.16)$, highlighting the role of applied litter as the source of these elements in surface runoff.

Mercury concentrations in surface runoff also correlated with loads ( $r=0.88)$, but $\mathrm{Hg}$ loads were also somewhat correlated with runoff depths $(r=0.67)$, suggesting other controls on $\mathrm{Hg}$ mobility than the source controls dominating the transfers of As and $\mathrm{Zn}$. Notably, $\mathrm{Hg}$ loads in surface runoff were greatest from the subsurface applied litter treatment, statistically equivalent to the control and broadcast poultry litter treatments but significantly greater than the disked treatment. The compounded effect of slightly higher $\mathrm{Hg}$ concentrations in surface runoff and slightly higher surface runoff depths appear to have produced $\mathrm{Hg}$ loads in surface runoff that were statistically greater from the subsurface litter treatment than from the disked treatment. Since neither $\mathrm{Hg}$ concentration nor surface runoff depth differed significantly between these treatments, this may reflect a stochastic outcome, but may also be a combination of two processes whose effects were not strong enough to make a significant difference on their own (for example, $\mathrm{Hg}$ mobilized by surface disturbance combined with greater infiltration).

\section{Figure 5}

Chemographs of trace elements not found in applied poultry litter for the first rainfall simulation event.

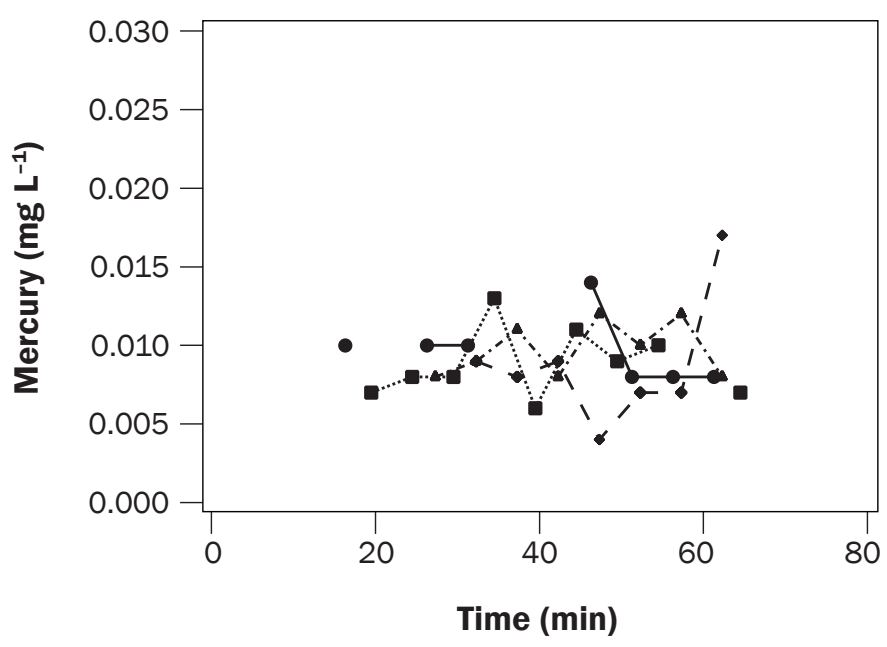

Legend

- Control …… Broadcast - - Disked -.. - Subsurface

Leaching. Leaching is often the dominant pathway for transport of litter-derived nutrients in coastal plain soils (Kleinman et al. 2007). In our experiments, the intense rainfall events of hour-long duration produced copious quantities of surface runoff that likely biased the relative contribution of this pathway to the fate of the trace elements from the lysimeters. Even so, substantial concentrations and loads of trace elements were observed in leachate. In addition to the three trace elements detected in surface runoff (As, $\mathrm{Hg}$, and $\mathrm{Zn}$ ), Se was also detected in leachate.

Concentrations of Dissolved Trace Elements in Leachate. For all elements, concentrations $\left(\mathrm{mg} \mathrm{L}^{-1}\right)$ in leachate were greater in the first event than in the second event. In the case of the trace elements applied in litter, particularly $\mathrm{Zn}$, this suggests their depletion from the applied source over the 2 rainfall simulation events and 11 semiweekly irrigation events occurring between the rainfall simulations. However, these lower concentrations in the second event may also reflect the depletion of more readily mobile edaphic sources. In the case of $\mathrm{Hg}$ and $\mathrm{Se}$, which could only be derived from edaphic sources, their occurrence in leachate from the first event likely reflects their equilibration in the soil solution via kinetically slow desorption and microbial transformations (Van Dorst and Peterson 1984; Porvari and Verta 1995) and subsequent mobilization.
Concentrations of $\mathrm{Hg}$ and $\mathrm{Se}$ in leachate from the first rainfall simulation event were significantly higher (twofold to fourfold) than were their concentrations in surface runoff. By the second event, concentrations of Se in leachate had declined below the limit of analytical detection. Mean concentrations of $\mathrm{Hg}$ in leachate for all treatments, including the control, were above the federal drinking water standard for both events (USEPA 2009). Concentrations of $\mathrm{Zn}$ in leachate were significantly higher for the first event than they were in surface runoff (1.5 times to two times greater), but concentrations of $\mathrm{Zn}$ in leachate and surface runoff were of similar magnitude by the second event. In contrast, As concentrations tended to be lower in leachate than in surface runoff, varying significantly by litter application treatment for the first event and declining to below detection limits for the second event. Concentrations of As in leachate from some of the litter treatments were above the federal drinking water standard for the first event (USEPA 2009).

With the exception of As concentrations in leachate for the first event, there were no significant differences in leachate concentrations between litter application treatments for any of the elements in the study (table 2). For As, subsurface applied litter produced leachate concentrations that were significantly higher than the disked treatment and the unamended control, but not signifi- 


\section{Table 4}

Mean trace element loss in surface runoff and leachate from two rainfall simulation events.

\begin{tabular}{|c|c|c|c|c|c|c|c|c|c|}
\hline \multirow[b]{2}{*}{ Treatment } & \multirow[b]{2}{*}{$\mathbf{N}$} & \multicolumn{2}{|l|}{ Arsenic } & \multicolumn{2}{|l|}{ Mercury } & \multicolumn{2}{|l|}{ Selenium } & \multicolumn{2}{|l|}{ Zinc } \\
\hline & & $\begin{array}{l}\text { Surface } \\
\text { runoff }\end{array}$ & Leachate & $\begin{array}{l}\text { Surface } \\
\text { runoff }\end{array}$ & Leachate & $\begin{array}{l}\text { Surface } \\
\text { runoff }\end{array}$ & Leachate & $\begin{array}{l}\text { Surface } \\
\text { runoff }\end{array}$ & Leachate \\
\hline \multicolumn{10}{|c|}{ 1st rainfall simulation (15 d after litter application) } \\
\hline Broadcast & 5 & $12.20 \mathrm{a}$ & $1.53 a$ & $3.37 a b$ & $3.61 a$ & $<\mathrm{MDL}$ & $1.21 a$ & $80.57 a$ & $50.73 a$ \\
\hline Broadcast/disked & 5 & $4.50 a b$ & $1.00 a$ & $2.16 \mathrm{~b}$ & $6.02 a$ & $<\mathrm{MDL}$ & $1.55 a$ & $40.37 a b$ & $45.33 a$ \\
\hline Control & 5 & $2.96 a$ & $<\mathrm{MDL}$ & $<M D L$ & $<M D L$ & $<\mathrm{MDL}$ & $<M D L$ & $11.02 \mathrm{a}$ & $3.66 a$ \\
\hline Broadcast & 5 & $5.13 a$ & $<\mathrm{MDL}$ & $<M D L$ & $<\mathrm{MDL}$ & $<\mathrm{MDL}$ & $<\mathrm{MDL}$ & $26.15 a$ & $4.35 a$ \\
\hline Broadcast/disked & 5 & $3.37 a$ & $<\mathrm{MDL}$ & $<\mathrm{MDL}$ & $<M D L$ & $<\mathrm{MDL}$ & $<\mathrm{MDL}$ & $10.16 a$ & $4.47 a$ \\
\hline Subsurface & 5 & $7.49 a$ & $<\mathrm{MDL}$ & $<\mathrm{MDL}$ & $<\mathrm{MDL}$ & $<\mathrm{MDL}$ & $<\mathrm{MDL}$ & $15.93 a$ & $6.64 a$ \\
\hline \multicolumn{10}{|c|}{ Cumulative properties across both rainfall simulation events } \\
\hline Subsurface & 5 & $15.42 a b$ & $2.24 a$ & $5.05 a$ & $3.38 \mathrm{a}$ & $<\mathrm{MDL}$ & $1.14 a$ & $71.63 a b$ & $34.52 a$ \\
\hline
\end{tabular}

Notes: Values followed by different letters identify groupings per Tukey's mean separation analysis. $\alpha=0.05 . \mathrm{N}=$ number of samples. $<\mathrm{MDL}=$ below method detection limit.

cantly higher than the broadcast treatment. Trends in dissolved As concentration related to poultry litter application method are generally comparable to those reported by Feyereisen et al. (2010) for P, which is not surprising given that they have similar chemistries and source. In that study, subsurface litter application increased total dissolved $\mathrm{P}$ in leachate nearly fivefold above leachate concentrations with broadcast application, which were at least three times greater than those observed with disking or unamended (control) treatments. They attributed the elevated $\mathrm{P}$ concentrations in broadcast and subsurface litter application treatments to litter $\mathrm{P}$ translocation along macropores. Disking of soils disturbs the continuity of soil macropores and has been shown to significantly curtail $\mathrm{P}$ translocation from applied sources in a variety of soils (Geohring et al. 2001; Kleinman et al. 2009). This mechanism should apply to $\mathrm{Zn}$ as well, and it is surprising that no significant differences were observed in leachate $\mathrm{Zn}$ concentrations. This is likely due to the cationic nature of $\mathrm{Zn}$ and abundant $\mathrm{Zn}$ sorption sites in soils when compared with As.

Loads of Dissolved Trace Elements in Leachate. As with surface runoff, the association of leachate depth $(\mathrm{cm})$, trace element concentration $\left(\mathrm{mg} \mathrm{L}^{-1}\right)$, and trace element load $\left(\mathrm{g} \mathrm{ha}^{-1}\right)$ varied by expected source (litter or soil). For As and Zn, strong correlations were observed between leachate concentra- tion and load ( $r=0.92$ for both elements), further evidence of an acute source of these elements (i.e., litter) controlling their release to leachate. For $\mathrm{Hg}$ and $\mathrm{Se}$, no significant correlations were observed between their concentration and load in leachate, but strong relationships were observed between leachate depth and trace element load $(r=$ 0.86 for $\mathrm{Hg} ; r=0.75$ for $\mathrm{Se}$ ), pointing to a more pervasive source.

Virtually all of the As was lost in the two rainfall events (table 4), with the exception of the broadcast/disked treatment (where 82\% of the applied As was lost). The largest loads of As in leachate occurred in the first event following application, with losses in surface runoff three to eight times greater than those in leachate. Due to the compound variances of leachate flow and As concentration, the significant differences detected in leachate As concentrations between litter application treatments were not detected in As loads.

A significant fraction of $\mathrm{Zn}$ (up to $79 \%$ ) applied in litter was recovered in both surface runoff and leachate (table 4). As with As, $\mathrm{Zn}$ loads were greatest in the first leaching event. However, unlike As, Zn loads in surface runoff and leachate were roughly similar. Furthermore, loads of $\mathrm{Zn}$ in leachate did not differ significantly between litter application treatments, reflecting the surprising absence of $\mathrm{Zn}$ concentration differences, discussed earlier.
For $\mathrm{Hg}$, leachate loads in the first event were significantly higher than those observed in the second, while Se leachate loads were not detected in the second event. This was consistent with temporal trends in $\mathrm{Hg}$ and Se concentrations. No significant differences in leachate $\mathrm{Hg}$ and Se load were observed between treatments. For $\mathrm{Hg}$, loads via surface runoff and leachate were of similar magnitude in the first event, but $\mathrm{Hg}$ loads in leachate had diminished by the second event such that they were threefold to fourfold lower than loads in surface runoff.

\section{Summary and Conclusions}

Findings point to several generalizations regarding trace element losses in surface runoff and leachate from soils receiving manures.

Results indicate improved management of As in applied sources as key to its control. Most to all of the As applied was lost in the two rainfall events, with the largest losses occurring in the first event following application. Incorporating litter into soils with disk tillage resulted in lower losses of As to surface runoff than did broadcasting litter, where As in litter was left vulnerable to removal by runoff water. Incorporation by disking also resulted lower losses of As to leachate than did subsurface application, which concentrated litter in below-ground pockets.

Though Zn showed slightly greater retention in soil than As, much of the $\mathrm{Zn}$ applied was also lost in combined surface runoff and 
leachate $(50 \%$ to $79 \%)$, with comparable amounts being lost by both pathways. As with As, $\mathrm{Zn}$ in overland flow did respond to different litter application methods with similar relative reductions in concentration and load when incorporated either by disking or subsurface application. However, $\mathrm{Zn}$ in leachate was not significantly affected by litter application methods.

Mercury and Se were found in either surface runoff $(\mathrm{Hg})$ or leachate $(\mathrm{Hg}$ and $\mathrm{Se})$, although they did not occur in applied poultry litter. Selenium was only detected in the leachate, and no samples in the study approached the thresholds of concern. Furthermore, Se in the agricultural soil occurred at levels similar to those found in nearby forest soils, suggesting native sources. In contrast, $\mathrm{Hg}$ was detected in the agricultural soil and was found in surface runoff and leachate at levels of concern. This $\mathrm{Hg}$ likely derived from historical amendments. While concentrations of $\mathrm{Hg}$ were not affected by litter application methods, loads in surface runoff did differ between two of the litter application treatments. This difference is most likely stochastic.

\section{Acknowledgements}

Funding for this project was provided, in part, by the National Oceanic and Atmospheric Administration's Cooperative Institute for Coastal and Estuarine Environmental Technology program and the University of Maryland Eastern Shore (UMES) Agricultural Experiment Station. The authors would like to thank Don Mahan (farm technician at UMES) David Otto, Michael Reiner, Todd Strohecker, and Terry Troutman (USDA Agricultural Research Service) for help in collecting lysimeters and conducting rainfall simulations. Thanks are also extended to Janice Donahoe (laboratory specialist at UMES) Joan Weaver, Paul Spock, and Charles Montgomery (USDA ARS) for conducting laboratory experiments.

\section{Disclaimer}

USDA requires that the following statements be published with this manuscript: USDA is an equal opportunity provider and employer and mention of trade names or commercial products in this publication is solely for the purpose of providing specific information and does not imply recommendation or endorsement by the US Department of Agriculture.

\section{References}

Adams, E., A. Garcia-Sanchez, F. Santos, E. Velazquez, and M. Adams-Melendez. 2007. Immobilizationof mercury in soils of Venezuela using phospho-gypsum and sulphate-reducing bacteria. In E. Velazequez and C. Rodriguez-Barrueco (eds.), First International Meeting of Microbial Phosphate Solubilizaton, 333-336. New York: Springer.

Church, C.D., P.J.A. Kleinman, R.B. Bryant, L.S. Saporito, and A.L.Allen. 2010. Occurrence of arsenic and phosphorus in ditch flow from litter-amended soils and barn areas. Journal of Environmental Quality 39:2080-2088.

Delmarva Poultry Industry Inc. 2009. 2009 Facts about Delmarva's Broiler Chicken Industry. Georgetown, DE: Delmarva Poultry Industry Inc. http://www. dpichicken.org.

Feyereisen, G.W., and G.J. Folmar. 2009. Development of a laboratory-scale lysimeter system to simultaneously study runoff and leaching dynamics. Transactions of American Society of Agricultural and Biological Engineers 52:1585-1591.

Feyereisen, G.W., P.J.A. Kleinman, G.J. Folmar, L.S. Saporito, T.R. Way, C.D. Church, and A.L. Allen. 2010. Effect of direct incorporation of poultry litter on phosphorus leaching from coastal plain soils. Journal of Soil and Water Conservation 65(4):243-251, doi:10.2489/jswc.65.4.243.

Garbarino J.R., A.J. Bednar, D.W. Rutherford, R.S Beyer, and R.L. Wershaw. 2003. Environmental fate of roxarsone in poultry litter. I. Degradation of roxarsone during composting. Environmental Science and Technology 37:1509-14.

Geohring, L.D., O.V. McHugh, M.T. Walter, T.S. Steenhuis, M.S. Akhtar, and M.F. Walter. 2001. Phosphorus transport into sub-surface drains by macropores after manure applications: Implications for best manure management practices. Soil Science 166:896-909.

Gilkeson, J. 2002. Mercury use: Agriculture. In Wisconsin Mercury Sourcebook. Chicago, IL: US Environmental Protection Agency, Great Lakes National Program Office. http://www.p2pays.org/ref/04/03851.htm.

Gupta, G., and S. Charles. 1999. Trace elements in soils fertilized with poultry litter. Poultry Science 78:169.

Harter, R.D., and R. Naidu. 1995. Role of metal-organic complexation in metal sorption by soils. Advances in Agronomy 55:219-263.

Jackson, B.P., P.M. Bertsch, M.L. Cabrera, J.J. Camberato, J. C. Seaman, and C.W. Wood. 2003. Trace element speciation in poultry litter. Journal of Environmental Quality 32:535-540.

Kingery, W.L., C.W. Wood, D.P. Delaney, J.C. Williams, and G.L. Mullins. 1994. Impact of long term land application of broiler litter on environmentally related soil properties. Journal of Environmental Quality 23:139-147.

Kleinman, P.J.A., A.L. Allen, B.A. Needelman, A.N. Sharpley, P.A. Vadas, L.S. Saporito, G.J. Folmar and R.B. Bryant. 2007. Dynamics of phosphorus transfers from heavily manured coastal plain soils to drainage ditches. Journal of Soil and Water Conservation 62:225-235

Kleinman, P.J.A., A.N. Sharpley, L.S. Saporito, A.R. Buda, and R.B. Bryant. 2009. Application of manure to no-till soils: Phosphorus losses by sub-surface and surface pathways. Nutrient Cycling in Agroecosystems 84:215-227.

Kleinman, P.J.A., A.N. Sharpley, T.L.Viet, R.O. Maguire, and P.A. Vadas. 2004. Evaluation of phosphorus transport in surface runoff from packed soil boxes. Journal of Environmental Quality 33:1413-1423.

Maguire, R.O., P.J.A. Kleinman, C. Dell, D.B. Beegle, R.C. Brandt, J.M. McGrath, and Q.M. Ketterings. 2011. Manure management in reduced tillage and grassland systems: A review. Journal of Environmental Quality 40:292-301.
Matthews, E.D., and R.L. Hall. 1966. Soil survey of Somerset County, Maryland. Washington, DC: US Government Printing Office.

McDowell, R., and A. Sharpley. 2002. Phosphorus transport in overland flow in response to position of manure application. Journal of Environmental Quality 31:217-227.

Moore, P.A., Jr., T.C. Daniel, J.T. Gilmour, B.R. Shreve, D.R. Edwards, and B.H. Wood.1998. Decreasing metal runoff from poultry litter with aluminum sulfate. Journal of Environmental Quality 27:92-99.

Nicholson, F.A., B.J. Chambers, J.R. Williams, and R.J. Williams. 1999. Heavy metal contents of livestock feeds and animal manures in England and Wales. Bioresource Technology 70:23-31.

Porvari, P., and M. Verta. 1995. Methylmercury production in flooded soils: A laboratory study. Water Air and Soil Pollution 80:765-773.

Pote, D.H., T.R. Way, P.J.A. Kleinman, P.A. Moore, J.J. Meisinger, K.R. Sistani, L.S. Saporito, A.L. Allen, and G.W. Feyereisen. 2011. Subsurface application of poultry litter in pasture and no-till soils. Journal of Environmental Quality 40:402-411.

SAS Institute. 2000. The SAS system, version 8.0. Cary, NC: SAS Institute.

Sharpley, A.N., P.J.A. Kleinman, R.W. McDowell, M. Gitau, and R.B. Bryant. 2002. Modeling phosphorus transport in agricultural watersheds: Processes and possibilities. Journal of Soil and Water Conservation 57:425-439.

Sims, J.T. 1995. Characteristics of animal wastes and waste amended soils: An overview of the agricultural and environmental issues. In K. Steele (ed.), Animal Waste and the Land-Water Interface, 1-14. Boca Raton, FL: CRC Press.

US Code of Federal Regulations. 2012. 21 CFR 558.30, US Code of Federal Regulations. Washington, DC: Government Printing Office.

USEPA (US Environmental Protection Agency). 2009. National primary drinking water regulations. Washington, DC: US Environmental Protection Agency. http://water.epa.gov/drink/contaminants/ upload/mcl-2.pdf.

Van Dorst, S.H., and P.J. Peterson. 1984. speciation in the soil solution and its relevance to plant uptake. Journal of the Science of Food and Agriculture 35:601-605.

Verbree, D.A., S.W. Duiker, and P.J.A. Kleinman. 2010. Runoff losses of sediment and phosphorus from no-till and cultivated soils receiving dairy manure. Journal of Environmental Quality 39:1762-1770. 